\title{
A GENERATÍV TERVEZÉS LÉPÉSEI INTEGRÁLT CAD RENDSZEREKBEN
}

\author{
Szabó Kristóf \\ PhD hallgató, Miskolci Egyetem, Szerszámgépek Intézeti Tanszéke \\ 3515 Miskolc, Miskolc-Egyetemváros, e-mail: szabo.kristof@uni-miskolc.hu \\ Hegedüs György \\ egyetemi docens, Miskolci Egyetem, Szerszámgépek Intézeti Tanszéke \\ 3515 Miskolc, Miskolc-Egyetemváros, e-mail: hegedus.gyorgy@uni-miskolc.hu
}

\begin{abstract}
Absztrakt
Az ipar számos területének folyamatos fejlödése hatására, mint például a korszerü gyártóeszközök, az anyagtechnológia a számitógép és a szoftveres fejlettség lehetövé teszi a megszokott gyártástechnológiák körének bövitését. Az alábbiak közé sorolható az additív gyártástechnológia, amely új lehetöséget nyújt a mindennapi termékek elóállitására, ezáltal a piaci igények kiszolgálására. $A z$ integrált CAD rendszerek évtizedek óta elfoglalták helyüket a terméktervezés- és fejlesztés folyamatában, amely részben megreformálta a klasszikus tervezéstani módszereket és azon lépéseit.
\end{abstract}

Kulcsszavak: terméktervezés módszertana, topológiai optimalizálás, generatív tervezés

\begin{abstract}
Due to the continuous development of many areas of the industry, such as modern production equipment, material technology, computer and software development, it is possible to expand the range of conventional production technologies. These include additive manufacturing technology, which provides a new opportunity to produce everyday products, thereby satisfying market needs. Integrated CAD systems have occupied a place in the product design and development process for decades, which has partially reformed classical design methods and its steps.
\end{abstract}

Keywords: product design methodology, topology optimisation, generative design

\section{Bevezetés}

Egy sikeres termék megfelel az adott időszak müszaki fejlettségi szintjének és kielégíti a társadalom által megfogalmazott igényeket. A mérnöki tervezés célja, hogy egy-egy megfogalmazott problémára mind müszaki, mind gazdasági szempontból is megfelelő megoldást hozzon létre. A terméktervezés és fejlesztés kiemelkedő és különleges szakma, ugyanis nagy tapasztalatot, egyedi látásmódot és további sajátos képességeket igényel. Régen elfogadott volt az a szemlélet, hogy a sikeres terméktervezéshez szükséges tudás, valamilyen belső adottság, amely teljes mértékben nem tanulható, nem leírható, nem egzakt tudomány és nem gépesíthető. Rövid időn belül felismerésre került, hogy egy termék minőségét nagy mértékben befolyásolja a tervezési fázisban definiált és megfelelően kiválasztott koncepció. Továbbá a tervezési folyamat során felmerülő döntések sorozata meghatározó szerepet játszik a termék előállítási folyamatában, ahol előnyös és előnytelen változásokat eredményezhet. Ezen filozófia alapján, elmondható, hogy egy termék életútját tekintve az innovációs tevékenységek hatalmas erőforrásokat emésztenek fel. Kiindulva abból, hogy ezt a fajta tevékenységet csak az arra 
kompetens személy képes megfelelően elvégezni, a tervezési és fejlesztési munkálatok költséges és hosszadalmas folyamatnak bizonyulnak. A piac által diktált fokozódó elvárásoknak akkor lehet minél jobban megfelelni, ha egy adott termék minél hamarabb és minél kevesebb anyagi ráfordítás mellett kerülhet forgalomba. Ennek megfelelően a tervezöi, konstruktőri feladatokat sokak által elvégezhető feladattá kell alakítani, amelyben az egyes szakaszok és lépések jól követhetők és teljesíthetők [1].

\section{A tervezésmódszertan fejlődésének mérföldkövei}

A különféle tervezésmódszertani folyamatok fejlödése az elmúlt száz évhez köthetők. A tudományterülethez füződő irodalmak főként Európában születtek, de a világ számos országából találhatók olyan kutatók, akinek a munkássága ehhez a tématerülethez füződik. A kutatások célja változatlan, a tervezési folyamatot különböző szakaszokra bontva jól értelmezhető, követhető lépésekre kell bontani, hogy az sokak számára szélesebb körökben alkalmazható legyen. KESSELRING már 1937-től publikált az értékelö eljárásokról, majd mutatta be konvergens közelítő eljárásának alapjait. WÖGERBAUER 1943-ban tett javaslatot arra, hogy a teljes tervezői folyamatot részfeladatokra kell osztani. Az ilmenaui iskola megalapozói BISCHOFF és HANSEN voltak. HANSEN már az 1950-es évek óta foglalkozott a tervezésmódszertan alapjaival, a rendszerére vonatkozó elvi szempontokat 1965-ben foglalta össze. A berlini iskola megalapítója BEITZ, akinek a munkássága szorosan összekapcsolódik a darmstadti tervezőiskola megteremtőjével, PAHLlal. 1974ben ROTH az elsők között volt, akik felismerték, hogy a módszeres tervezés sikeresen automatizálható a grafikus számítógépek segítségével, majd kidolgozott egy algoritmikus tervezői modellt. Magyarországon említésre méltó a budapesti tervező iskola, mely a terméktervezés módszertanának és az eszközeinek fejlesztésével és kutatásával foglalkozik. Ezen tématerület hazai megalapozója BERCSEY, aki kidolgozta az Autogenetikus Algoritmust. Fontos megemlíteni a miskolci tervezőiskolát, amelyet TERPLÁN és TAJNAFÖI alapozott meg, továbbá LIPÓTH és TAKÁCS számítógépes struktúrageneráló módszereket dolgozott ki [2].

\section{A generatív tervezés és az integrált CAD rendszerek}

A generatív tervezési modell képes koncepciókat előállítani az előre definiált követelmények és korlátozások felhasználásával. Az eljárást, beleértve az alak- és topológiai optimalizálást az 1990-es évek környékén fejlesztették ki, de akkoriban még nem sikerült áttörő sikert eredményezni vele.

A programok használata nehézkes volt, a számítógépek kapacitása nem bizonyult elegendőnek, de a legfontosabb visszahúzó erő az volt, hogy a kapott eredményt nem lehetett elóállítani az adott kor hagyományos gyártástechnológiái segítségével. A következő 20 évben az adalékanyagok gyártása lehetőséget adott a 3D nyomtatás megvalósítására és a kétezres évek elején egyértelmüvé vált, hogy lehetőség válik nagy teljesítményü fémes alkatrészek additív gyártására, amely felkeltette az érdeklődést az integrált szoftverek gyártóinak körében. A generatív tervezést támogató szoftverek a 2010-es évek első felében jelentek meg. Elsők közt említhető meg a Frustum céghez köthető TrueSOLID ${ }^{T M}$, amelynek fejlesztője Jesse Coors-Blankenship. A másik nagy fejlesztő az AutoDesk, de felismerve a generatív tervezés igényét egyre több szoftverfejlesztő terméke vált elérhetővé, amelyeket az 1. táblázat foglal össze. 


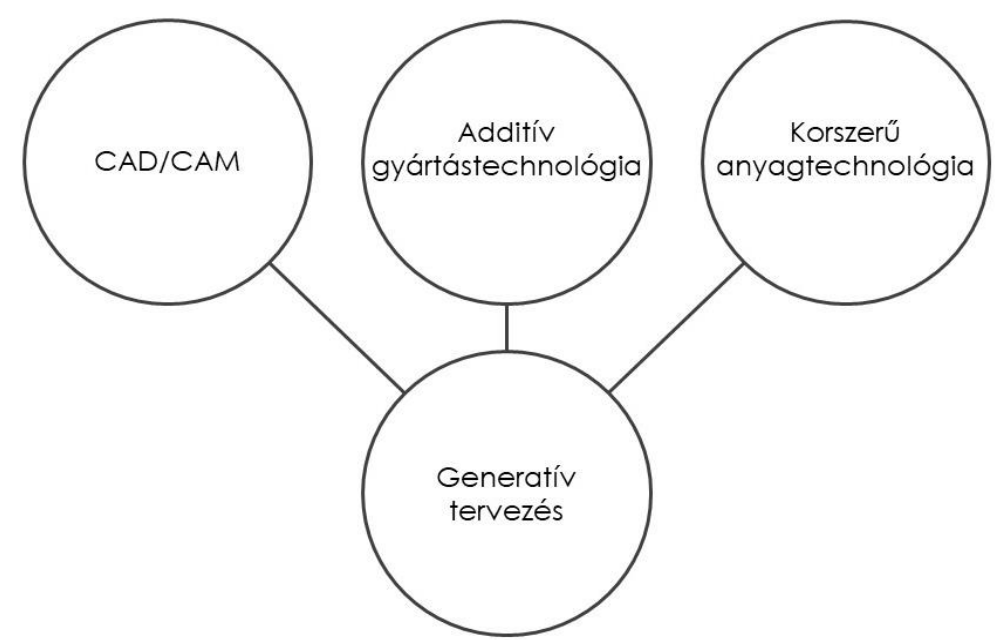

1. ábra. A generatív tervezés technológiaigénye

1. táblázat. Generativ tervezőszoftverek [3]

\begin{tabular}{|c|l|l|}
\hline \multirow{4}{*}{ Generatív tervezőszoftverek } & \multicolumn{1}{c|}{ Szoftverfejlesztő } & \multicolumn{1}{c|}{ Termék } \\
\cline { 2 - 3 } & Frustum & Generate \\
\cline { 2 - 3 } & nTopology & Element \\
\cline { 2 - 3 } $\begin{array}{c}\text { Generatív tervezést támogató } \\
\text { CAE szoftverek }\end{array}$ & Paramatters & CogniCAD \\
\cline { 2 - 3 } & Altair & OptiStruct \\
\cline { 2 - 3 } & Dassault Systèmes & ANSYS Mechanical \\
\cline { 2 - 3 } & ESI Group & Tosca Structure, Tosca Fluid \\
\hline \multirow{4}{*}{$\begin{array}{c}\text { Integrált rendszerek } \\
\text { generatív tervezó modullal }\end{array}$} & MSC Software & $\begin{array}{l}\text { PAM-STAMP, ProCAST, } \\
\text { SYSTUS }\end{array}$ \\
\cline { 2 - 3 } & Autodesk & MSC Nastran Optimization \\
\cline { 2 - 3 } & Dassault Systèmes & Fusion 360, Inventor \\
\cline { 2 - 3 } & Robert McNeel \& Associates & ROSCA suite \\
\cline { 2 - 3 } & Siemens & Creo Simulate \\
\cline { 2 - 3 } & Altair & NX, Solid Edge \\
\hline
\end{tabular}




\section{A generatív tervezés lépései integrált CAD rendszerekben}

A generatív tervezés olyan tervezési folyamat, amelyben egy algoritmus segítségével az alkatrész alakját egy adott határfeltételhez optimalizálja. Maga a forma megtervezése nem kézi tervezési feladat. A tervező meghatározza az alkatrész funkcionális peremfeltételeit, betáplálja a szoftverbe, amely a meghatározott szempontok szerint, iterációs folyamatok során kiszámolja az optimalizált alkatrész alakját [4]. A határállapotok általában két csoportra oszthatók, a számításhoz kiindulási geometria szükséges, amelyet hagyományos 3D-s modellezés útján kell elkészíteni. Ez teljesen hasonlít a hagyományos FEM rendszerekben alkalmazott megoldásra: meg kell határozni, hogy a darab melyik területét milyen erők és milyen kényszerek terhelik [5-7]. Egy másik lehetőség azon térfogatok meghatározása, amelyekben nem lehet anyag, mert például valami más alkatrész mozog ott. Ha nincs kezdő munkadarab, akkor azt „térfogatrészként” kell megadni, amelyek a kész alkatrész részei lesznek. A következőkben részletezésre kerülnek a generatív tervezési folyamat lépései, amelyek érvényesek és hasonlóságot mutatnak az 1. táblázatban feltüntetett valamennyi integrált CAD rendszer használatával.

Az adott program megnyitása után, az első lépésünk a tervezési térfogat definiálása, amelyhez három lehetőség áll rendelkezésünkre. Ennek első módja a megtartandó geometriák meghatározása, amely változatlan módon, a kapott geometria szerves része marad. Ezek megadása kötelező művelet, majd a későbbiekben ezen testek és felületek adnak lehetőséget funkciók definiálására, például furatok elhelyezése. A tervezési tér második metódusa az úgynevezett akadályozó geometriák definiálása, amely segítségével megadhatjuk a tér azon részeit, ahol nem lehet anyag. A program által elöállított geometria csak ezen térrészen kívül helyezkedhet el, de hasonló módon alkalmazhatjuk az alkatrész méretkorlátozása esetén is. A tervezés során ezen térfogatok megadása nem kötelező. A harmadik módszer egy szilárdtest modell beimportálása, amelynek alaksajátosságai felhasználhatók a funkciók megadásához. Ebben az esetben az eredeti modell külső felülete alapértelmezett módon nem korlátozza a generatív tervezés folyamán előállított geometria befoglaló méretét.

A tervezési tér pontos meghatározása után következhet a folyamat második szakasza, amely során definiálhatjuk a modellünk rögzítési pontjait és további kényszereit. Lehetőség nyílik fix pontok megadására, de van mód azon belül az egyes síkok és forgástengelyek feloldására. Van lehetőségünk csukló vagy forgáspont létrehozására, ahol radiális, axiális és tangenciális mozgás engedélyezhető. Továbbá módunkban állhat csúszási síkokat és súrlódó felületpárokat meghatározni.

A tervezés harmadik szakaszában jutunk el a terhelések helyének és nagyságának definiálásához. Lehetőségünk adódik erő, nyomás, nyomaték és megoszló terhelés elhelyezésére, amelyeknek iránya és nagysága korlátlanul módosítható.

Negyedik lépésben kell döntést hozni a tervezési kritériumokról és célkitüzésekröl. Ez lehet a tömeg minimalizálása, a merevség maximalizálása vagy a minimális feszültség kialakulása és annak optimális eloszlása. Ebben a fázisban állítható be egy úgynevezett biztonsági faktor.

Ötödik lépésben lehetőség van a gyártási módszer megválasztására, ahol kiválaszthatjuk a gyártási volument és a megfelelő gyártástechnológiát. A választható technológiák közé tartozik az additív gyártás, forgácsoló eljárások, mint például a marás, vágás és az öntés. Minden egyes opció esetén megválasztható a modellre vonatkozó minimális anyagvastagság és az adott technológiában alkalmazott szerszámok, mint például a marószerszám geometriai mérete, valamint a megmunkálás iránya. Fennáll annak a lehetősége is, hogy ez a lépés kiválasztás nélkül marad, ilyenkor a modellek generálása szélesebb körben engedélyezett.

A folyamat hatodik lépésében meg kell választanunk azt az anyagot, amelyből majd a gyártmány készülhet. A kiválasztás létrejöhet a programok anyagkatalógusaiból, de módunkban állhat új anyag 
definiálására egyedi tulajdonságokkal. A katalógusban szereplő elemek anyagjellemzői minden további nélkül módosíthatók. Ügyelni kell arra, hogy minden gyártástechnológiának meg van az ahhoz kompatibilis anyagok halmaza.

Az említett beállítások elvégzése után elérhetővé válik egy ellenőrző lépés, amely végig futtatja az általunk betáplált adatokat és adathiány vagy rosszul betáplált feltételek esetén figyelmeztetést ad a felhasználó számára.

Ha az ellenőrzés megtörtént, indítható a tervezés, vagyis a végső számítás és generálás folyamata. A kapott megoldásokat lehetőségünk van kategóriák szerint szürni és az egyes alkatrészek iterációs eredményeihez hozzáférni.

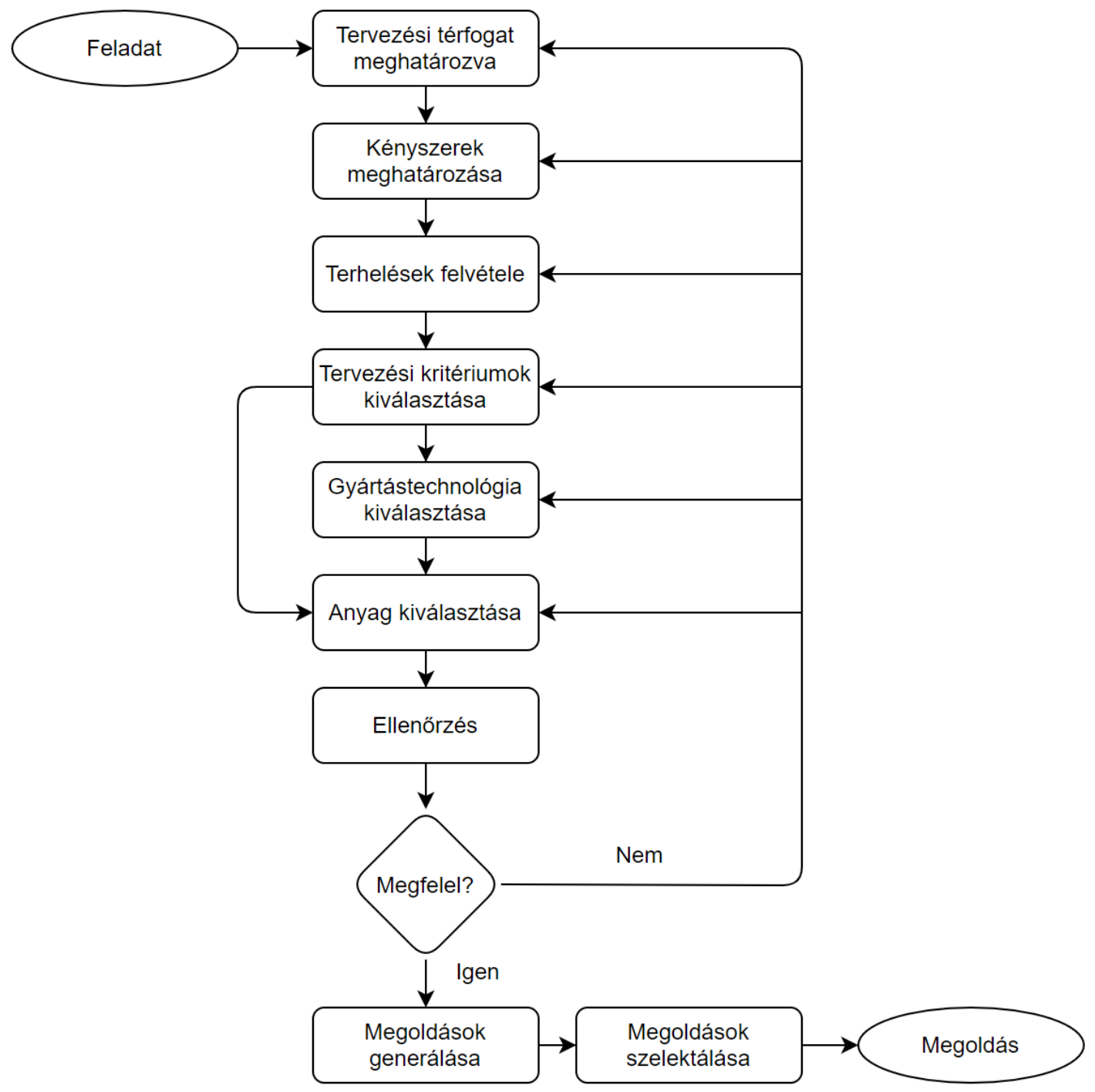

2. ábra. A generativ tervezési folyamat lépései 


\section{5. Összefoglalás}

Az alábbi cikkben áttekintésre került generatív tervezést megalapozó terméktervezés- és fejlesztés szakterület fejlödése, valamint annak meghatározó állomásai. Bemutatásra kerültek a generatív tervezési eljárás elterjedését befolyásoló tényezők és a szükséges technológiai folyamatok fejlődése, valamint a cikk egy rövid történeti áttekintés folyamán összefoglalást nyújt az eljárást támogató szoftverek témájában. A felsorolt szoftverek függvényében a cikk leírja a módszer használatához szükséges lépéseket, amelyek egyezést mutatnak a különféle programok esetén. A gyors megértés és szemléltetés érdekében megrajzolásra került a módszer müködtetéséhez füződő folyamatábra, a lehetséges iterációk kiegészítésével. A lépéseket megfelelően betartva és követve, sikeres megoldásokat kapunk a megfogalmazott feladatra.

\section{Köszönetnyilvánítás}

A cikkben ismertetett kutató munka az EFOP-3.6.1-16-2016-00011 jelü „Fiatalodó és Megújuló Egyetem - Innovatív Tudásváros - a Miskolci Egyetem intelligens szakosodást szolgáló intézményi fejlesztése" projekt részeként - a Széchenyi 2020 keretében - az Európai Unió támogatásával, az Európai Szociális Alap társfinanszírozásával valósul meg.

\section{Irodalom}

[1] Takács, Gy., Zsiga, Z., Szabóné Makó, I., Hegedüs, Gy.: Gyártóeszközök módszeres tervezése, Nemzeti Tankönyvkiadó, Miskolc, 2011.

[2] Kamondi, L., Sarka, F., Takács, Á.: Fejlesztés- módszertani ismeretek, Nemzeti Tankönyvkiadó, Miskolc, 2011.

[3] An Introduction to Generative Design - A Digital Guide from the Editors of Cadalyst, Cadalyst, Longitude Media, 2018, https://cadalyst.tradepub.com/free/w_cada04/prgm.cgi

[4] Szabó, K., Hegedűs, Gy.: A generativ tervezést támogató szoftverek rövid áttekintése, Multidiszciplináris Tudományok 2020, 10(3):328-337. https://doi.org/10.35925/j.multi.2020.3.39

[5] Zuo, K., Chen, L., Zhang, Y., Yang, J.: Study of key algorithms in topology optimization, The International Journal of Advanced Manufacturing Technology 2007, 32:787-796. https://doi.org/10.1007/s00170-005-0387-0

[6] Bendsøe, M.: Optimization of Structural Topology, Shape, and Material, Springer, Berlin, 1995. ISBN 978-3-662-03117-9, https://doi.org/10.1007/978-3-662-03115-5

[7] Rozvany, G.: Aims, scope, methods, history and unified terminology of computer-aided topology optimization in structural mechanics, Structural and Multidisciplinary Optimization 2001, 21:90-108. https://doi.org/10.1007/s001580050174 